\title{
Assessing the Effects of Higher-Education Factors on the Job Satisfaction of Engineering Graduates in Korea
}

\author{
Jiyoung Yoon ${ }^{1}$, Soojung Park ${ }^{2}$ and Dae-Jin Kim ${ }^{2, *(1)}$ \\ 1 Innovation Center for Engineering Education, Seoul National University of Science and Technology, \\ Seoul 01811, Korea; jyoon@seoultech.ac.kr \\ 2 Innovation Center for Engineering Education, Kyung Hee University, Yongin 17104, Korea; sj1222@khu.ac.kr \\ * Correspondence: djkim@khu.ac.kr
}

Received: 22 March 2020; Accepted: 19 April 2020; Published: 20 April 2020

\begin{abstract}
This paper investigates the relationship between the influential factors related to higher education and job satisfaction of engineering graduates in Korea. The education factors considered in this study can be categorized into three groups: those related to personal information, satisfaction with higher-education quality, and participation in career development programs. The Graduates Occupational Mobility Survey data collected in 2016 and provided by the Korea Employment Information Service were used to evaluate the job satisfaction of Korean engineering graduates, which was in turn analyzed using the hierarchical multiple regression approach. The verification of the statistical analysis results indicates the importance of school location and high satisfaction with overall school quality in determining the job satisfaction of engineering graduates in Korea. It also reveals that internship is more efficient in enhancing job satisfaction than relatively short-term programs such as interviews, resume coaching, and job camps.
\end{abstract}

Keywords: career development program; engineering graduates; job satisfaction; engineering education; hierarchical multiple regression; Graduates Occupational Mobility Survey

\section{Introduction}

In recent years, South Korea has been one of the top countries listed in the program for international student assessment (PISA) [1] and trends in international mathematics and science study (TIMSS) [2]. According to the population with tertiary education published by the OECD (Organization for Economic Co-operation and Development) [3], the admission rate to higher education programs in South Korea is approximately $70 \%$, which is well above the average rate of $43.1 \%$.

In addition, South Korea has been one of world leading countries in regard to information and communication technology (ICT) development. For example, South Korea was ranked first in the world on high-speed internet penetration rate, first in the number of people using the internet, and second on global smartphone market share in 2012 [4]. Furthermore, the ICT sector is a resilient pillar of the Korean economy, which accounted for $10.4 \%$ of value added, the largest share across the OECD in 2017 [5]. It was also reported in 2018 that ICT business accounted for more than $14 \%$ of Korean GDP and $30 \%$ of Korean exports [6].

With this background, the universities in Korea have been developing various career development programs in order to increase the proportion of the ICT market in the national economy and to support its sustainable development. Examples of career development programs include personality tests for jobs, interview and resume coaching, career consultation, and job camps. Their main purpose is to help engineering students to set their career goals, to foster skills that can be immediately utilized in 
industry and to provide them useful information about the jobs they may have after graduation. This experience helps them to find jobs that they can be satisfied with and to make a successful career.

There are many factors that can affect job satisfaction. Previous research showed that the gender, age, and higher-education type of an individual affect job satisfaction [7], and the quality of major curriculum and the overall satisfaction with higher education provided are also crucial factors determining job satisfaction [8]. There has been some research in which the effects of career development programs are analyzed, but most has focused on the effects of a specific career development program on the job satisfaction of engineering graduates. Roh et al. [9] and Chung et al. [10] revealed that participation in career development programs makes a positive effect on overall job satisfaction after graduation. Chaudhary and Bhasker [11] investigated the effects of training and development programs in higher education on job satisfaction, and Majewski [12] insisted that a variety of experience during the university education period positively affects students' careers after graduation. Job satisfaction at the internship stage was investigated by Smayling and Miller [13].

This study aims at categorizing various higher-education related factors and systematically investigating their effects on the job satisfaction of engineering graduates in Korea. We utilized the Graduates Occupational Mobility Survey data collected in 2016 and provided by Korea Employment Information Service to evaluate the job satisfaction of Korean engineering graduates [14]. The survey results of 4874 participants selected from the GOMS database were analyzed using the hierarchical multiple regression model, in which three sets of independent variables, such as personal information, satisfaction with the quality of higher education, and participation in career development programs, are hierarchically entered. This study is based on the hypothesis that the three sets of independent variables affect the job satisfaction of Korean engineering graduates after graduation. Then, the results of the model verification were analyzed and discussed. The components of career development programs making positive effects on job satisfaction can be identified from the results of this study. This information can be helpful in reorganizing the curricula of higher education facilities in Korea and improving their quality.

The outline of this paper is as follows. Following the introduction, in Section 2, we discuss the characteristics of the GOMS database, dependent and independent variables, and statistical strategies utilized in this study. Section 3 identifies the data distribution from the results of standard descriptive statistics and verifies the difference in the job satisfaction averages of the independent variables. Furthermore, the correlation among all variables is identified and the results of the model verification for the three models are discussed. Finally, the summary and concluding remarks are provided in Section 4 .

\section{Methodology}

\subsection{Research Data}

This study targeted 4874 young Korean graduates possessing BS degrees in engineering among 18,057 Korean people, who participated in the Graduates Occupational Mobility Survey (GOMS) in 2016 [14]. The GOMS is the largest short-term panel survey in Korea to collect a representative sample of Korean workers, who graduated from two- or three-year college courses or universities. It started in 2006 and has been carried out annually since then. This survey mainly investigated their labor market behavior and educational experience, including educational background, job training, certificates, job seeking experience, personal and family information, job satisfaction, and turnover, which can affect entrance and integration into the labor market. Consequently, it can provide policy makers and researchers with basic information that can be utilized for employment policy making and in-depth studies for unemployment problems.

The 4874 young Korean engineers who were the targets of this study can be categorized based on three criteria, which are gender, school type, and school location as listed in Table 1. All of them were under the age of 29 , which is the limit for young people considering the high university entrance rate 
and military service obligation for male citizens in Korea. They consisted of 3942 males and 932 females, which corresponded to $81.6 \%$ and $18.4 \%$ of the total participants of this study, respectively. Among the targets of this research, 877 engineers graduated from the schools located in the capital region in Korea, and the rest of them (3997 engineers) from those located in non-capital regions. The school types can be divided into university (3550 engineers) and college (1324 engineers).

Table 1. Statistical summary of the targets of this study.

\begin{tabular}{ccccc}
\hline & \multicolumn{2}{c}{ Variable } & Frequency & \% \\
\hline \multirow{2}{*}{ Gender } & Male & 3942 & 80.9 \\
\cline { 2 - 4 } & & Female & 932 & 19.1 \\
\hline \multirow{2}{*}{ Undergraduate school type } & 2- or 3-year college course & 1324 & 27.2 \\
\cline { 2 - 4 } & & University & 3550 & 72.8 \\
\hline \multirow{2}{*}{ School location } & Capital (Seoul) & 877 & 18.4 \\
\cline { 2 - 4 } & & Others & 3997 & 81.6 \\
\hline & Total & 4874 & 100.0 \\
\hline
\end{tabular}

\subsection{Study Variables}

This section discusses the selection of the sets of dependent and independent variables which were utilized in the statistical analysis. These variables were taken from the survey questions of the GOMS performed in 2016. The independent variables were determined considering previous research on the factors influential to the job satisfaction of employees, such as personal information, satisfaction with the quality of higher education, and participation in career development programs.

There have been a number of previous investigations, which showed that personal information such as gender, age, higher-education type, GPA (grade point average), and school location affect overall job satisfaction. Several researchers $[7,15]$ reported that male workers generally show higher job satisfaction than females. Age is also an important factor affecting job satisfaction. Job stability generally increases as a worker's age increases, but younger candidates are preferred by employers [16,17]. The type of higher education and school location are important factors determining job satisfaction since four-year university courses and capital region-located schools are highly preferable to two- or three-year college courses and institutions located in non-capital regions, respectively, in Korea [18]. Schulze and Kool et al. $[19,20]$ indicated that GPA is also an influential factor to job satisfaction.

It was reported by several researchers that satisfaction with the quality of higher education affects overall job satisfaction after graduation. Oshagbemi [8] indicated that employees' satisfaction with the faculty and their teaching methods and quality are influential factors in job satisfaction. Robst [21] emphasized that the quality of the major curriculum of higher education affects employees' job satisfaction.

There has been some research which analyzed the effect of a specific career development program on the job satisfaction of engineering graduates. However, relatively little research has been performed in regard to the comparison and analysis of the effects of different components of career development programs on job satisfaction after graduation. The components of the career development programs provided by higher education in Korea include job training programs, personality tests for jobs, interview and resume coaching, career consultation, and job camps. Roh et al. [9] reported that participation in career development programs increases both the employment rate and the level of job satisfaction in Korea. Chung et al. [10] revealed that participation in career development programs makes a positive effect on overall job satisfaction for both two- and three-year college course and university graduates in Korea. Smayling and Miller [11] suggested that the experience of internship helps job seekers to enter into the labor market and to improve their job satisfaction. 
Based on the discussion above, we selected the three sets of independent variables summarized in Table 2. Each independent variable corresponds to a single question item taken from the GOMS survey database. The independent variables have a different scale depending on the type of the question, as presented in the table. Table 3 lists thirteen components measuring the job satisfaction of the Korean engineering graduates, which is the dependent variable of the statistical study. Each component in the list is also a single question item taken from the GOMS survey database and is represented by a 5-point scale, as shown in the table. This study utilized the secondary data taken from the GOMS database. For reliability analysis of the job satisfaction scale, the value of Cronbach's alpha was calculated and it is 0.92 as given in Table 3, confirming its high reliability.

Table 2. Independent variables.

\begin{tabular}{|c|c|c|c|}
\hline & Variable & \# of Items & Scale \\
\hline \multirow{2}{*}{$\begin{array}{c}\text { Personal } \\
\text { information }\end{array}$} & Age & 1 & Score \\
\hline & Higher-education type & 1 & $\begin{array}{l}\text { University/2- or 3-year college } \\
\text { course (code: } 0 / 1)\end{array}$ \\
\hline \multirow{3}{*}{$\begin{array}{l}\text { Satisfaction with } \\
\text { the quality of } \\
\text { higher education }\end{array}$} & Major curriculum satisfaction & 1 & \multirow[b]{3}{*}{5 points $(1 \sim 5)$} \\
\hline & Faculty satisfaction & 1 & \\
\hline & Teaching method and quality satisfaction & 1 & \\
\hline \multirow{5}{*}{$\begin{array}{c}\text { Participation in } \\
\text { career development } \\
\text { programs }\end{array}$} & Internship & 1 & \multirow{5}{*}{ Yes/No (code: 0/1) } \\
\hline & Personality test for jobs & 1 & \\
\hline & Career consultation & 1 & \\
\hline & Interview and resume coaching & 1 & \\
\hline & Job camp & 1 & \\
\hline
\end{tabular}

Table 3. Dependent variables.

\begin{tabular}{|c|c|c|c|}
\hline Variable & \# of Items & Scale & Cronbach's alpha \\
\hline Income & 1 & \multirow{13}{*}{5 points $(1 \sim 5)$} & \multirow{14}{*}{0.92} \\
\hline Job stability & 1 & & \\
\hline Quality of work environment & 1 & & \\
\hline Working hours & 1 & & \\
\hline Possibility of personal development & 1 & & \\
\hline Human relationships & 1 & & \\
\hline Welfare benefits & 1 & & \\
\hline Promotion system & 1 & & \\
\hline Social reputation of tasks given at work & 1 & & \\
\hline Work autonomy & 1 & & \\
\hline Social reputation of job & 1 & & \\
\hline $\begin{array}{l}\text { Compatibility between the job } \\
\text { characteristics and one's aptitude }\end{array}$ & 1 & & \\
\hline $\begin{array}{l}\text { Work-related training or support for } \\
\text { training }\end{array}$ & 1 & & \\
\hline Total & 13 & $13 \sim 65$ & \\
\hline
\end{tabular}




\subsection{Strategies for Statistical Analysis}

The statistical analysis of this study was performed by following three steps as described below. First, we identified the distribution of the variables for use in the study from the results of standard descriptive statistics. Next, we examined the difference in the job satisfaction averages of two independent variables evaluated in terms of score, which are the personal information and participation in career development programs. Lastly, we investigated the correlation of variables to confirm whether these variables were suitable for statistical regression analysis and verified the prediction models for all independent variables affecting job satisfaction by performing hierarchical multiple regression analysis.

The hierarchical multiple regression was performed in a stepwise fashion to judge the relative importance of a predictor variable over and above other important predictors [22]. This approach focused on the change in predictability associated with the predictor variables entered later over and above the contributions by the variables entered earlier in the analysis [23]. It is also important to note that theoretical background needed to be provided in determining the order of entry of predictor variables.

For the hierarchical multiple regression analysis performed in our study, we considered the three sets of independent variables, discussed in Section 2.2, which affect job satisfaction. The set of five personal information-related variables were used as predictors in the first regression model (Model 1), as it was the most difficult to change among the three sets of variables. Then, four variables related to satisfaction with higher-education quality were added to the second regression model, while statistically controlling for the five variables entered in the previous step (Model 2). Lastly, six variables of participation in career development programs were added to the third model, while controlling for all of the nine variables entered in the first and second steps (Model 3).

These models can be represented below in linear regression Equations (1) through (3), respectively. Here, $X_{0}$ is a vector of gender, age, school type, GPA, and school location variables. $X_{1}$ is a vector of major curriculum satisfaction, major faculty satisfaction, teaching method and quality satisfaction, and school overall satisfaction. $X_{2}$ is a vector of job training programs, internships, personality tests for jobs, career consultation, interview and resume coaching, and job camps. The statistical analysis was performed by using the well-known statics software SPSS 21.0 (SPSS Inc., Chicago, IL, USA).

$$
\begin{gathered}
Y=A X_{0} \\
Y=A X_{0}+B X_{1}, \\
Y=A X_{0}+B X_{1}+C X_{2} .
\end{gathered}
$$

\section{Results and Discussion}

\subsection{Descriptive Analysis and Difference Test}

This section identified the data distribution from the results of standard descriptive statistics and verified the difference in the job satisfaction averages of two independent variables evaluated in terms of score, such as personal information and participation in career development programs. Table 4 summarizes descriptive statistics for all independent variables considered in this study. 
Table 4. Descriptive statistics.

\begin{tabular}{|c|c|c|c|c|}
\hline & Variable & & $\begin{array}{c}\text { Mean or } \\
\text { (Proportion) }\end{array}$ & SD \\
\hline & Job satisfaction & & 39.63 & 8.66 \\
\hline \multirow{6}{*}{ Personal information } & \multirow{2}{*}{ Gender } & Male & $(0.80)$ & \\
\hline & & Female & $(0.20)$ & \\
\hline & \multirow{2}{*}{ Type of higher education } & 2- or 3-year college course & $(0.37)$ & \\
\hline & & University & $(0.63)$ & - \\
\hline & \multirow{2}{*}{ School location } & Capital (Seoul) & $(0.13)$ & \\
\hline & & Other regions & $(0.87)$ & \\
\hline \multirow{4}{*}{$\begin{array}{c}\text { Satisfaction with } \\
\text { higher-education } \\
\text { quality }\end{array}$} & \multicolumn{2}{|c|}{ Major curriculum satisfaction } & 3.37 & 0.88 \\
\hline & \multicolumn{2}{|c|}{ Faculty satisfaction } & 3.52 & 0.91 \\
\hline & \multicolumn{2}{|c|}{ Teaching method and quality satisfaction } & 3.40 & 0.85 \\
\hline & \multicolumn{2}{|c|}{ School overall satisfaction } & 3.40 & 0.84 \\
\hline \multirow{12}{*}{$\begin{array}{l}\text { Participation in career } \\
\text { development programs }\end{array}$} & \multirow{2}{*}{ Job training program } & Y & $(0.46)$ & \\
\hline & & $\mathrm{N}$ & $(0.54)$ & \\
\hline & \multirow{2}{*}{ Internship } & Y & $(0.26)$ & \\
\hline & & $\mathrm{N}$ & $(0.74)$ & \\
\hline & \multirow{2}{*}{ Personality test for jobs } & Y & $(0.46)$ & \\
\hline & & $\mathrm{N}$ & $(0.54)$ & - \\
\hline & \multirow{2}{*}{ Career consultation } & Y & $(0.34)$ & \\
\hline & & $\mathrm{N}$ & $(0.66)$ & \\
\hline & \multirow{2}{*}{$\begin{array}{l}\text { Interview and resume } \\
\text { coaching }\end{array}$} & $\mathrm{Y}$ & $(0.39)$ & \\
\hline & & $\mathrm{N}$ & $(0.61)$ & \\
\hline & \multirow{2}{*}{ Job camp } & $\mathrm{Y}$ & $(0.17)$ & \\
\hline & & $\mathrm{N}$ & $(0.83)$ & \\
\hline
\end{tabular}

Table 5 shows the verification results of the difference in the job satisfaction averages of the two independent variables evaluated in terms of score, which were personal information and participation in career development programs. The difference verification of the personal information is first discussed. The average job satisfaction of the male and female participants was 39.43 and 40.41, respectively, indicating a statistically non-significant (N.S.) result with $t=-1.52$. The difference verification of the type of higher education found that average job satisfaction was 39.53 and 39.69 for graduates of two- or three-year college courses and universities, respectively, indicating a statistically non-significant (N.S.) result with $t=-0.30$. The school location was statistically significant with $t=1.68$ and $p<0.10$, and the average of graduates of capital region located schools was 40.76 while the result for others was 39.46 .

As for the difference verification of the participation in career development programs, the average of internship participants was 40.79 , which was higher than that of those not participating in internships (39.36). This indicates that participation in internship programs makes a positive impact on job satisfaction after graduation $(t=2.48, p<0.05)$. The average of graduates who took the personality test for jobs was 40.19, higher than 39.34, which was the average of the others $(t=1.70, p<0.10)$. In contrast, the average of graduates who attended job camps was 38.96, while that for others was 39.88. This indicates that the former showed lower job satisfaction than the latter $(\mathrm{t}=-1.37, p<0.10)$. 
Table 5. Verification of the difference in the job satisfaction averages of two independent variables evaluated in terms of score.

\begin{tabular}{|c|c|c|c|c|c|c|}
\hline & Variable & & $\mathbf{N}$ & Mean & SD & $t$ \\
\hline \multirow{6}{*}{$\begin{array}{c}\text { Personal } \\
\text { information }\end{array}$} & \multirow{2}{*}{ Gender } & Male & 881 & 39.43 & 8.94 & \multirow{2}{*}{-1.52} \\
\hline & & Female & 227 & 40.41 & 7.42 & \\
\hline & \multirow{2}{*}{$\begin{array}{l}\text { Type of higher } \\
\text { education }\end{array}$} & 2- or 3-year college course & 414 & 39.53 & 8.46 & \multirow{2}{*}{-0.30} \\
\hline & & University & 694 & 39.69 & 8.78 & \\
\hline & \multirow{2}{*}{ School location } & Capital (Seoul) & 144 & 40.76 & 8.86 & \multirow{2}{*}{$1.68^{+}$} \\
\hline & & Other regions & 964 & 39.46 & 8.62 & \\
\hline \multirow{12}{*}{$\begin{array}{l}\text { Participation } \\
\text { in career } \\
\text { development } \\
\text { programs }\end{array}$} & \multirow{2}{*}{ Job training program } & $\mathrm{Y}$ & 508 & 40.07 & 8.81 & \multirow{2}{*}{1.24} \\
\hline & & $\mathrm{N}$ & 598 & 39.44 & 7.98 & \\
\hline & \multirow{2}{*}{ Internship } & $\mathrm{Y}$ & 283 & 40.79 & 8.70 & \multirow{2}{*}{$2.48^{*}$} \\
\hline & & $\mathrm{N}$ & 823 & 39.36 & 8.22 & \\
\hline & \multirow{2}{*}{ Personality test for jobs } & $\mathrm{Y}$ & 507 & 40.19 & 8.76 & \multirow{2}{*}{$1.70^{+}$} \\
\hline & & $\mathrm{N}$ & 599 & 39.34 & 8.01 & \\
\hline & \multirow{2}{*}{ Career consultation } & Y & 374 & 40.01 & 8.85 & \multirow{2}{*}{0.81} \\
\hline & & $\mathrm{N}$ & 732 & 39.58 & 8.11 & \\
\hline & \multirow{2}{*}{$\begin{array}{c}\text { Interview and resume } \\
\text { coaching }\end{array}$} & $\mathrm{Y}$ & 436 & 39.64 & 8.91 & \multirow{2}{*}{-0.27} \\
\hline & & $\mathrm{N}$ & 670 & 39.78 & 8.00 & \\
\hline & \multirow{2}{*}{ Job camp } & Y & 186 & 38.96 & 9.67 & \multirow{2}{*}{$-1.37^{+}$} \\
\hline & & $\mathrm{N}$ & 920 & 39.88 & 8.08 & \\
\hline
\end{tabular}

\subsection{Results of Model Verification}

The correlation evaluation among all variables revealed that the correlation coefficients (r) between the independent and dependent variables ranged from 0.00 to 0.19 and the correlation coefficients among all independent variables were smaller than the limit equal to 0.90 discussed in [24]. As a result, no problem of multi-collinearity occurred, and the model verification was acceptable.

Table 6 presents the results of the model verification for the three models discussed in Section 2.3. The correlation among the variables was very low, and thus no problem of multi-collinearity occurred. In Model 1, the effects of personal information on job satisfaction were identified. It can be observed from the results of this model that graduates from non-capital region-located schools showed lower job satisfaction than those from capital region-located schools $(B=-1.54, t=-1.94, p<0.05)$. The effects of other variables such as age, gender, type of higher education, and GPA on job satisfaction are not shown to be statistically significant.

The results of Model 2, where the independent variables related to satisfaction with the quality of higher education were additionally considered, indicated that high satisfaction with major curriculum $(\mathrm{B}=0.84, \mathrm{t}=2.05, p<0.05)$ and overall school quality $(\mathrm{B}=0.98, \mathrm{t}=2.32, p<0.001)$ increased job satisfaction after graduation. In contrast, the variables of faculty satisfaction and teaching method and quality did not show any statistically significant results. The effects of the five personal information-related variables were shown to be similar to the results in Model 1.

From the results of Model 3, it can be seen that graduates with the experience of participating in internship programs showed high job satisfaction $(B=1.52, t=2.41, p<0.05)$, while participants in job camps had low job satisfaction $(B=-1.58, t=-2.13, p<0.05)$. In addition, job training programs $(B=0.17)$, personality tests for jobs $(B=0.66)$, and career consultation $(B=0.14)$ had a positive effect on increasing job satisfaction, whereas interview and resume coaching $(B=-0.47)$ resulted in a negative effect, although they were not statistically significant results. In this model, the effects of the other independent variables that have already been entered into Models 1 and 2 were also similar to the previous results. 
Table 6. Results of model verification (\# of observations = 1132).

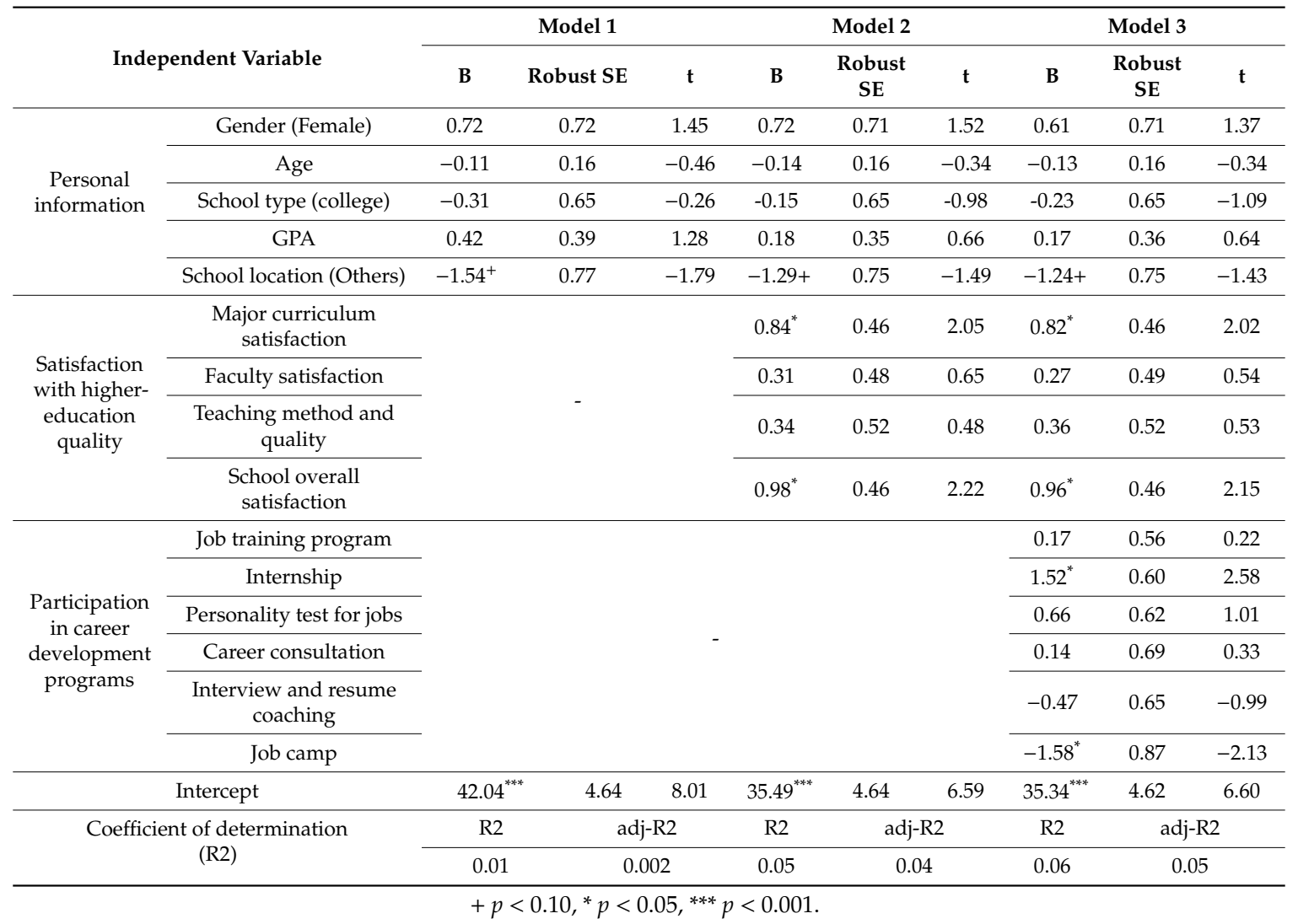

From these results, we can draw the following conclusions. First, school location is a very important factor in determining the job satisfaction of engineering graduates in Korea. This seems to be because most excellent higher-education institutions are located near the capital region in Korea, the quality of their students is also high, and thus their graduates generally show very good performance once they enter into the job market. This result reveals a unique situation in Korea, in which most main infrastructure and social functions are highly centralized in the capital region.

Second, high satisfaction with major curriculum and overall school quality have a positive effect on increasing job satisfaction after graduation. This coincides with the conclusions of previous research reported in $[25,26]$. This suggests that the overall quality of higher-education content is more important than minor factors such as school location, and thus it is essential to improve the quality of higher education in order to achieve high job satisfaction among graduates.

Third, internship is more efficient in enhancing job satisfaction than relatively short-term programs such as interview and resume coaching and job camps. Although these short-term programs may provide an opportunity to learn technical skills helpful in improving the possibility of employment, they are not helpful for undergraduate students seeking to find a job suitable for their interests and background. Internship programs are an essential component in the German university education system as it requires that all undergraduate students participate in an internship before graduation [27]. Participation in internship programs can expand graduates' knowledge from on-the-job experience and improve their adaptability in the workplace as discussed in [28]. Consequently, it is desirable that career development programs focus on internship programs to enhance job satisfaction.

\section{Conclusions}

In this study, we categorized various higher-education related factors in order to systematically investigate their effects on the job satisfaction of engineering graduates in Korea. We utilized the 
GOMS data collected in 2016 and provided by the Korea Employment Information Service. The survey results of 4874 participants selected from the GOMS database were analyzed using the hierarchical multiple regression model, in which three sets of independent variables, such as personal information, satisfaction with the quality of higher education, and participation in career development programs, were hierarchically entered. From the results of the model verification, the following conclusions can be obtained:

1) The verification results of the difference in the job satisfaction averages indicate that graduates from capital region-located school show high job satisfaction and participation in internship programs and personal tests for jobs are helpful in increasing job satisfaction after graduation.

2) School location is a very important factor in determining the job satisfaction of engineering graduates in Korea, revealing a unique situation in Korea, where most main infrastructure and social functions are highly centralized in the capital region.

3) High satisfaction with major curricula and overall school quality have a positive effect on increasing job satisfaction after graduation, emphasizing the importance of the quality of higher education.

4) Internship is more efficient in enhancing job satisfaction than relatively short-term programs such as interviews, resume coaching, and job camps.

Some additional comments regarding the limitations of this study and future work are as follows. First, job satisfaction refers to a single dependent variable in this study as in the GOMS survey questions. However, different dimensions or various sub-factors of job satisfaction may result in different interpretations of the statistical analysis. These different dimensions could be identified by performing a factor analysis in our future research. Second, the insignificant effects of school type and GPA on job satisfaction may be attributed to the fact that differences in students' ability caused differences in their income or job expectations. This issue could be further explored by investigating the effects of school type and GPA on the students' income or job expectations in our future research. Lastly, the GOMS database utilized in this study is the result of self-reporting tests, and thus it may be worth performing an additional study, a quantitative evaluation of the achievement and results of engineering graduates at work in Korea, if available, and comparing its results with those provided in this paper.

Author Contributions: In this paper, J.Y. and S.P. proposed the main concept of the research; J.Y. developed the methodology and performed statistical analysis using computer software; J.Y. and D.-J.K. compared and analyzed the results of the statistical data; J.Y. and D.-J.K. wrote the entire manuscript; S.P. reviewed and edited the completed manuscript; D.-J.K. acquired funding for the research. All authors have read and agreed to the published version of the manuscript.

Funding: This research was supported by Korea Institute for Advancement of Technology (KIAT) grant funded by the Korea Government (MOTIE). (N0001338, Innovative Engineering Education).

Acknowledgments: This research was supported by Korea Institute for Advancement of Technology (KIAT) grant funded by the Korea Government (MOTIE). (N0001338, Innovative Engineering Education).

Conflicts of Interest: The authors declare no conflict of interest.

\section{References}

1. OECD. PISA 2018 Insight and Interpretations; OECD: Paris, France, 2018; pp. 1-64.

2. IEA. TIMSS 2015 International Results; IEA: Chestnut Hill, PA, USA, 2015; pp. 1-10.

3. OECD. Population with tertiary education. Available online: https://www.oecd-ilibrary.org/education/ population-with-tertiary-education/indicator/english_0b8f90e9-en (accessed on 2 December 2019).

4. National Information Society Agency. National Information Society Agency. Based on the Evaluation Results of Major Overseas Organizations Such as the OECD Current Status and Implications of Korea's ICT Infrastructure. AI Network Insight. 2; National Information Society Agency: Seoul, Korea, 2019.

5. KITA. Korea's Top 10 Trading Goods. Available online: http://stat.kita.net/stat/world/major/KoreaStats12. screen (accessed on 20 February 2020).

6. KITA. Key Indicators in OECD Countries. Available online: http://kosis.kr/statHtml/statHtml.do?orgId= 101\&tblId=DT_2KAAG01 (accessed on 14 January 2019). 
7. Bender, K.; Donohue, S.; Heywood, J. Job satisfaction and gender segregation. Oxf. Econ. Pap. 2005, 57, 479-496. [CrossRef]

8. Oshagbemi, T. Job satisfaction and dissatisfaction in higher education. Educ. Train. 1997, 39, 354-359. [CrossRef]

9. Roh, K.; Park, Y.H.; Hur, S.J. Analysis on the Relationship between Youth Workers' Experience in College Education Service and Job Transition. J. Voca. Educ. Res. 2011, 30, $29-49$.

10. Chung, M.N.; Lim, Y.S.; Park, G.Y. A Structural Equation Modeling on the Variables Influencing Turnover Intention of Youth. J. Future. Orient. Youth Soc. 2009, 6, 111-128.

11. Chaudhary, N.S.; Bhasker, P. Training and development and job satisfaction in education sector. Int. J. Busi. Quan. Econ. 2016, 2, 89-97.

12. Majewski, K.R. Does College Experience Matter? A National Study Understanding Graduates' Job Satisfaction. Ph.D. Thesis, Seton Hall University, South Orange, NJ, USA, 2018.

13. Smayling, M.; Miller, M. Job satisfaction and job performance at the internship level. J. Lead. ACC Ethics. 2012, 9, 27-33.

14. KEIS. GOMS 2015 Technical Report; KEIS: Sejong, Korea, 2017; pp. 1-16.

15. Clark, A.E. Job satisfaction and gender: Why are women so happy at work? Labour. Econ. 1997, 4, $341-372$. [CrossRef]

16. Boumans, N.P.; de Jong, A.H.; Janssen, S.M. Age-differences in work motivation and job satisfaction. The influence of age on the relationships between work characteristics and workers' outcomes. Int. J. Aging. Hum. Dev. 2011, 73, 331-350. [CrossRef] [PubMed]

17. Kumar, P.N.; Mohan, A.; Chand, K.K.K. A study of age factor on job satisfaction and remuneration leading to turnover trends, with reference to working professionals in India. Abhinav International Monthly Refereed. J. Res. Manag. Techn. 2014, 3, 7-13.

18. Huh, E.J. Factors Influencing Employment of Two-year College and Four-year University Graduates in Korea. Master's Thesis, Sejong University, Seoul, Korea, 2018.

19. Schulze, S. Factors influencing the job satisfaction of academics in higher education. SAJHE 2006, 20, 318-335. [CrossRef]

20. Kool, A.; Mainhard, M.T.; Jaarsma, A.D.C.; Brekelmans, M.; van Beukelen, P. Academic success and early career outcomes: Can honors alumni be distinguished from non-honors alumni? High. Abil. Stud. 2016, 27, 179-192. [CrossRef]

21. Robst, J. Education and job match: The relatedness of college major and work. Econ. Educ. Rev. 2007, 26, 397-407. [CrossRef]

22. Petrocelli, J.V. Hierarchical multiple regression in counseling research: Common problems and possible remedies. Meas. Eval. Couns. Dev. 2003, 36, 10-11. [CrossRef]

23. Fram, M.S.; Kim, J.; Sinha. Early care and prekindergarten care as influences on school readiness. J. Fam. Issues 2012, 33, 478-505. [CrossRef]

24. Dohoo, I.R.; Ducrot, C.; Fourichon, C. An overview of techniques for dealing with large numbers of independent variables in epidemiologic studies. Prev. Vet. Med. 1996, 29, 221-239. [CrossRef]

25. Kim, H.; Kil, H. Who Shows Higher Job Satisfaction? In regard with University Education. Asia J. Educ. 2017, 18, 145-167. [CrossRef]

26. Valentine, S.; Lynn, G.; Gary, M.F.; Roland, K. Corporate ethical values, group creativity, job satisfaction and turnover intention: The impact of work context on work response. J. Busi. Ethics. 2007, 98, 353-372. [CrossRef]

27. Korea Trade Association International Trade Research Institute. How do you nurture the science and engineering manpower that companies need? -Aachen Institute of Technology case analysis in Germany. Trade Brief. 2014, 20, 1-6.

28. Auer, M.E.; Kim, K.S. Engineering Education for a Smart Society; Springer: Cham, Switzerland, 2018; pp. 57-70.

(C) 2020 by the authors. Licensee MDPI, Basel, Switzerland. This article is an open access article distributed under the terms and conditions of the Creative Commons Attribution (CC BY) license (http://creativecommons.org/licenses/by/4.0/). 